of the frond, glands, sori position, and scales distinguish the $D$. goldiana $\times D$. intermedia hybrid from all other known Dryopteris hybrids. In a detailed study of $D$. goldiana $\times$ D. intermedia, Evans and Wagner (1964) emphasized that it looks like an unusually large individual of $D$. intermedia and often resembles $D$. intermedia more closely than $D$. goldiana.

Another hybrid woodfern involving $D$. goldiana was recently given a name, Dryopteris $\times$ mickelii Peck (D. clintoniana $\times$ goldiana), and was reported for the first time in the Ottawa district of eastern Ontario (Peck 2001; Cody 2002). This hybrid differs from the $D$. goldiana $\times D$. intermedia hybrid in the fronds being pinnate-pinnatifid on the basal pinnae instead of bipinnate-pinnatifid. The recently described Correll's Woodfern, Dryopteris correllii Wagner (D. carthusiana (Villars) H. P. Fuchs $\times D$. goldiana) is unlike $D$. goldiana $\times D$. intermedia in being eglandular throughout (Evans and Wagner 1964; Wagner and Gilman 2001).

Additional information on the distinctive characteristics of $D$. goldiana $\times D$. intermedia is available in Evans and Wagner (1964), Montgomery (1982), and Thorne and Thorne (1989).

\section{Acknowledgments}

The identification was confirmed by J. D. Montgomery. Useful comments were provided by W. J. Cody.

\section{Literature Cited}

Carlson, T. M., and W. H. Wagner, Jr. 1982. The North American distribution of the genus Dryopteris. Contributions of the University of Michigan Herbarium 15: 141-162.
Cody, W. J. 2002. Dryopteris $\times$ mickelii Peck, Simulated Log Fern, a newly named hybrid fern found in the Ottawa District. Trail \& Landscape 36: 43-45.

Cody, W. J., and D. M. Britton. 1989. Ferns and fern allies of Canada. Agriculture Canada Research Branch Publication 1829/E. 430 pages.

Evans, A. M., and W. H. Wagner, Jr. 1964. Dryopteris goldiana $\times$ intermedia, a natural hybrid woodfern cross of noteworthy morphology. Rhodora 66: 255-266.

Montgomery, J. D. 1982. Dryopteris in North America part II: the hybrids. Fiddlehead Forum (Bulletin of the American Fern Society) 9(4): 23-30.

Montgomery, J. D., and W. H. Wagner Jr. 1993. 9. Dryopteris Adanson. Pages 280-288 in Flora of North America Volume 2, Pteridophytes and Gymnosperms. Oxford University Press, New York.

Peck, J. H. 2001. Binomial for Dryopteris clintoniana $\times$ goldiana. American Fern Journal 91(1): 36-37.

Thorne, F., and L. Thorne. 1989. Henry Potter's field guide to the hybrid ferns of the northeast. Vermont Institute of Natural Science, Woodstock, Vermont.

Wagner, W. H., and A. V. Gilman. 2001. Dryopteris correllii hyb. nov. $(D$. carthusiana $\times$ goldiana $)$, a rare woodfern hybrid from Vermont. American Fern Journal 91(1): 9-12.

Wherry, E. T. 1961. The fern guide - northeastern and midland United States and adjacent Canada. Doubleday and Co., New York. 318 pages.

Whitham, T. G. 1991. Conservation of hybrid plants. Science 254: 779-780.

Whitham, T. G., and J. Maschinski. 1996. Current hybrid policy and the importance of hybrid plants in conservation. Pages 103-112 in Southeastern rare and endangered plants, proceedings of the second conference, Flagstaff, Arizona, U.S.A. 11-14 Sept. 1995. Edited by J. Maschinski, H.D. Hammond and L. Holter. General technical Report. Rocky Mountain Forest and Range Experiment Station, U.S. Department of Agriculture.

\title{
New Records of the Eastern Red Bat, Lasiurus borealis, from Cypress Hills Provincial Park, Saskatchewan: A Response to Climate Change?
}

\author{
Craig K. R. WiLlis ${ }^{1}$ and R. MARK Brigham
}

Department of Biology, University of Regina, Regina Saskatchewan, S4S 0A2 Canada

${ }^{1}$ Current address: Centre for Behavioural and Physiological Ecology, Zoology, University of New England, Armidale, New South Wales, 2351, Australia; e-mail: cwillis2@pobox.une.edu.au (corresponding author).

Willis, Craig K. R., and R. Mark Brigham. 2003. New records of the Eastern Red Bat, Lasiurus borealis, from Cypress Hills Provincial Park, Saskatchewan: a response to climate change? Canadian Field-Naturalist 117(4): 651-654.

During the summer of 2001 we captured two Eastern Red Bats (Lasiurus borealis) in Cypress Hills Provincial Park, Saskatchewan. A possible explanation for this range extension is a warming trend since 1965 documented for the area.

Key Words: Eastern Red Bat, Lasiurus borealis, new records, global warming, Cypress Hills, Saskatchewan.

Eastern Red Bats (Lasiurus borealis) are a wideranging vespertilionid found throughout most of the United States, much of South America and in southern Canada from the east coast to approximately the mid-longitude of Saskatchewan in the west (Shump and Shump 1982; Saskatchewan Environment and Resource Management 2001; Figure 1). This species roosts almost exclusively in the open foliage of trees (Shump and Shump 1982; van Zyll de Jong 1985). It is usually found near forests, often roosting along for- 
est edges, or in open areas where shade trees are present (Shump and Shump 1982). The Eastern Red Bat mates in the fall and gives birth to 1-5 pups (mean = 2.3) in the spring (Hamilton and Stalling 1972; Shump and Shump 1982). It is migratory and Canadian populations likely over-winter in the southern U.S., generally south of $40^{\circ} \mathrm{N}$ (Davis and Lidicker 1956), hibernating in the open foliage of trees or in tree cavities (Cowan and Guiget 1965). Of Canada's 19 species of bats, the red bat are the most easily identified because of their distinctive pelage. Dorsally, the Eastern Red Bat is rusty red in colour with whitish fur ventrally and a heavily furred interfemoral membrane. Indeed, the genus name Lasiurus literally means "hairy tail" (Shump and Shump 1982).

During the summer of 2001, while conducting research on bats in the West Block of Cypress Hills Provincial Park, Saskatchewan, we captured two Eastern Red Bats in mist nets. The first capture occurred at $23: 30$ on 24 July at a site $2.5 \mathrm{~km}$ east of the Saskatchewan-Alberta Border (49 $\left.37.5^{\prime} \mathrm{N}, 110^{\circ} 59^{\prime} \mathrm{W}\right)$ over the Battle Creek. The second capture occurred at 23:45 on 13 August, slightly further east, approximately $4.5 \mathrm{~km}$ from the Saskatchewan-Alberta border (49 $36^{\prime} \mathrm{N}, 110^{\circ} 56^{\prime} \mathrm{W}$ ), also over the Battle Creek.

For both bats we recorded sex, and age (adult or young of the year) was determined by examining the cartilaginous gap between the diaphysis of the metacarpal and proximal phalanx (Anthony 1988). Reproductive status was assessed by gentle palpation of the abdomen for pregnancy, expression of milk and bare patches around the nipples for lactation, and re-growth of fur around the nipples for post-lactation (Racey 1988). The individual captured in July was a nonreproductive adult female (mass $=14.5 \mathrm{~g}$, forearm $=$ $41.78 \mathrm{~mm}$, tibia $=21.64 \mathrm{~mm}$ ). The August individual was a reproductive female. She had bare nipples but milk could not be expressed so we cannot determine conclusively if she was in the late stages of lactation or early postlactation. Her body size was not measured.

The nearest record of $L$. borealis along the western fringe of its range is from Expanse, Saskatchewan, approximately $300 \mathrm{~km}$ to the east. This species has also been captured near Saskatoon, about 460 km northeast of the Cypress Hills, and one bat was captured in Calgary, Alberta. Van Zyll de Jong (1985) cites this occurrence of $L$. borealis west of Saskatchewan as accidental and suggests that this species' migratory wintering strategy may cause it to stray into territory outside its regular range. Our captures, however, suggest that this species is resident at least as far west as the Saskatchewan-Alberta border, for two reasons. First, one of the captures occurred in July, well outside the migration period. Barclay (1984) found that Red Bats moved through Delta Marsh, Manitoba, during spring and early fall but he never captured individuals during mid-summer. If the individual we captured was simply migrating through the Cypress Hills we would not expect to catch her in July.
Second, the individual captured in August was likely lactating, and therefore still roosting with her pre- or newly volant pups nearby, which suggests that $L$. borealis reside and raise young in the Cypress Hills. More work is needed, however, to confirm the presence of a breeding population because the reproductive individual could have been an early migrant. The Hoary Bat (Lasiurus cinereus), a closely related species with a very similar life history (migratory, roosts in open foliage), is known to continue nursing pups quite late in the season. Separation occurs when pups are approximately seven weeks of age and migration begins (Koehler and Barclay 2000). Based on radiotelemetry data, some resident mother/adult Hoary Bat groups separate and leave the Cypress Hills by midAugust, but most remain in the area until later in the month. Some early migrants, which leave the area within a day or two of capture, pass through the Cypress Hills in mid-late August, as well (Willis, unpublished data). Red bats may follow a similar pattern of staggered migration, so we cannot conclude that the individual we captured was rearing pups in the Cypress Hills. Radio-telemetry studies will be important for determining the reproductive status and roosting requirements of this species if it is captured in the area again.

Bat diversity is affected by the availability of suitable roosting habitat (Humphrey 1975). In this sense, the Cypress Hills are one area where a relatively high diversity of bats, especially foliage roosting species like Eastern Red Bats, is expected. Compared with the open prairie, which surrounds the region for hundreds of kilometers, the Cypress Hills have abundant roosting opportunities. In addition, roosting in open foliage may allow red bats to be relatively flexible in their choice of roost trees. For example, in Kentucky, red bats roosted in 13 different hardwood species and, among these, showed no species-specific preference, although they avoided conifers (Hutchinson and Lacki 2000). Given this flexibility, and the fact that the red bat's known range is a relatively short distance $(\sim 300 \mathrm{~km})$ to the east, one might expect to find this species in the Cypress Hills. However, in seven summers of sampling over the past decade (1991 1994 and 1999 - 2001) with roughly equal mist-netting effort, the records reported here are the first two for this species. By comparison, during the summers of 2000 and 2001 we captured over 25 Hoary Bats, over 30 Little Brown Bats (Myotis lucifugus), and over 30 Silver-haired Bats (Lasionycteris noctivigans) [Willis, unpublished data]. On the other hand, the relative abundance of some bat species may be underestimated based on mist-net captures alone. For example, in the Cypress Hills we know that Big Brown Bats (Eptesicus fuscus) are abundant because we capture 30-40 per year by trapping at Trembling Aspen (Populus tremuloides) cavity roosts, and observe hundreds more emerging from roosts, but we catch only 1-2 per year mist-netting over foraging areas along Battle Creek 


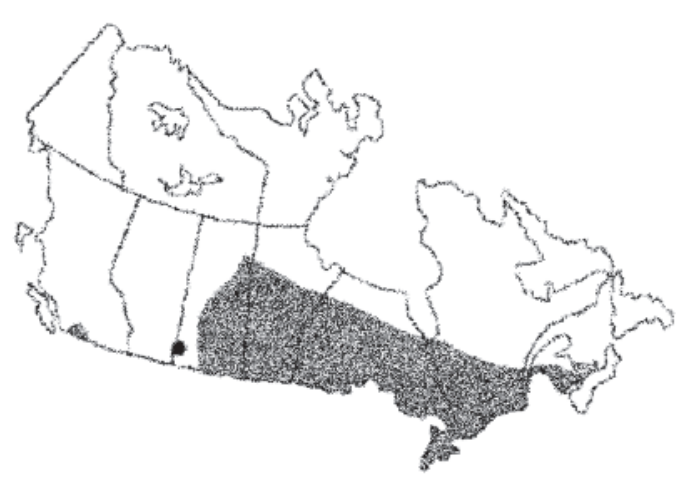

FIGURE 1. The current Canadian range of the Red Bat, Lasiurus borealis. The black dot represents the Cypress Hills where two individuals were captured during summer 2001.

[Willis, unpublished data]. Mist-net captures, then, may also underestimate Eastern Red Bats in the area.

One biologically relevant explanation for the rarity of red bats in the Cypress Hills could be this species' preference for deciduous trees over conifers (Hutchinson and Lacki 2000), which dominate much of the region's forest. This seems unlikely, however, given that Trembling Aspen are ubiquitous. Another explanation could be that the current presence of red bats is a response to climate change. The relatively high elevation of the Cypress Hills results in cold summer minimum temperatures compared to the surrounding prairie at similar latitudes, and nights with subfreezing temperatures are common especially in the spring. Red bats are known to occur in relatively cold areas in Canada, but do not range as far north as Hoary Bats (van Zyll de Jong 1985). Hoary Bats are common in the Cypress Hills, perhaps because of their larger body size and smaller body surface to volume ratio, which will result in lower rates of heat loss than red bats. Historically, red bats may have been prevented from exploiting the abundant roosting opportunities in the area because of a relatively cold climate. Based on data collected from the Agricultural Canada Research Station at Onefour, Alberta (less than $50 \mathrm{~km}$ to the west), mean minimum temperatures for the month of May have significantly increased in the region since 1965 (Figure 2). This warming trend could explain the presence of red bats in the area because warmer spring night-time temperatures would result in higher prey availability and reduced thermoregulatory costs at a critical time of year when bats are establishing maternity roosting sites prior to parturition. If, as predicted by many global climate change models, summer temperatures continue to increase, the Cypress Hills may become suitable to sustain a population of $L$. borealis. These captures, then, could have impli-

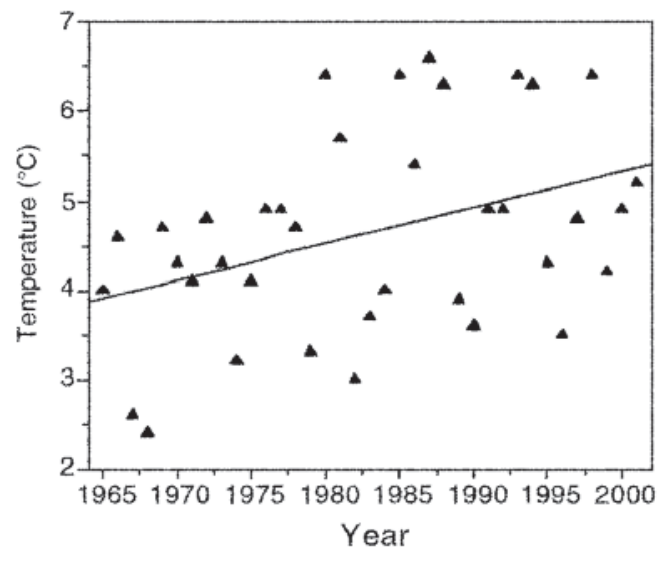

FIgURE 2. Mean minimum temperatures from 1965 to 2001 for May of each year, recorded from the Agriculture Canada Research Station at Onefour, Alberta, less than $50 \mathrm{~km}$ west of Cypress Hills, Saskatchewan. There is a significant warming trend $(\mathrm{P}=0.02, \mathrm{n}=37$, $\mathrm{r}^{2}=0.15$ ), which could account for a range expansion of Lasiurus borealis.

cations for predictions about range expansion in other animals as global climate continues to change, especially if $L$. borealis are captured in the Cypress Hills in the future.

\section{Acknowledgments}

We are grateful to Ray Poulin and Jeff Lane for comments on the manuscript. We also thank R. Fisher, C. Voss, S. Martinez and J. Adams for help in the field. Erin Bayne, Darren Bender, Ryan Csada, Quinn Fletcher, David Gummer, Kerry Hecker, Matina Kalcounis, Amanda Karst, October Negraeff and Darren Sleep have all collected mistnet data over the past decade. Our research in the Cypress Hills is supported by Mountain Equipment Co-op, Saskatchewan Environment and Resource Management, The University of Regina, and the Natural Sciences and Engineering Research Council of Canada.

\section{Literature Cited}

Anthony, E. L. T. 1988. Age determination in bats. Pages 31-46 in Ecological and Behavioral Methods for the Study of Bats. Edited by T. H. Kunz. Smithsonian Institute Press, Washington, D.C.

Barclay, R. M. R. 1984. Observations on the migration ecology and behaviour of bats at Delta Marsh, Manitoba. Canadian Field-Naturalist 98: 331-336.

Cowan, I. McT., and C. J. Guiget. 1965. The mammals of British Columbia. British Columbia Provincial Museum Handbook 11. 414 pages.

Davis, W. H., and W. Z. Lidicker. 1956. Winter range of the Red Bat, Lasiurus borealis. Journal of Mammalogy 37: 280-281.

Hamilton, R. B., and D. T. Stalling. 1972. Lasiurus borealis with five young. Journal of Mammalogy 53: 190. 
Humphrey, S. R. 1975. Nursery roosts and community diversity of Nearctic bats. Journal of Mammalogy 56: 321-346.

Hutchinson, J. T., and M. L. Lacki. 2000. Selection of day roosts by red bats in mixed mesophytic forests. Journal of Wildlife Management 64: 87-94.

Koehler, C. E., and R. M. R. Barclay. 2000. Post-natal growth and breeding biology of the Hoary Bat (Lasiurus cinereus). Journal of Mammalogy 81: 234-244.

Racey, P. A. 1988. Reproductive assessment in bats. Pages 57-95 in Ecological and Behavioral Methods for the Study of Bats. Edited by T. H. Kunz. Smithsonian Institution Press, Washington, D.C.
Saskatchewan Environment and Resource Management. 2001. Natural Neighbours: Selected Mammals of Saskatchewan. Canadian Plains Research Centre: Regina, Saskatchewan. 206 pages.

Shump, K. A. Jr., and A. U. Shump. 1982. Lasiurus borealis. Mammalian Species 183: 1-6.

Van Zyll de Jong. C. G. 1985. Handbook of Canadian Mammals 2: Bats. National Museums of Canada, Ottawa. 212 pages.

Received 17 December 2001

Accepted 4 May 2004

\title{
Marsh Rice Rat, Oryzomys palustris, Predation on Forster's Tern, Sterna forsteri, Eggs in Coastal North Carolina
}

\author{
JOHN H. BRUNJES IV ${ }^{1}$ and W. DAVID WeBSTER
}

Department of Biological Sciences, University of North Carolina at Wilmington, Wilmington, North Carolina 28403-3297 USA

${ }^{1}$ Current Address: Department of Range Wildlife, and Fisheries Management, Texas Tech University, Box 42125, Lubbock, Texas 79409 USA

Brunjes, John H., and W. David Webster. 2003. Marsh Rice Rat, Oryzomys palustris, predation on Forster's Tern, Sterna forsteri, eggs in coastal North Carolina. Canadian Field-Naturalist 117(4): 654-655.

Nesting success of Forster's Terns (Sterna forsteri) was examined on two small islands in the Cedar Island area of North Carolina. Forster's Terns laid an average of 2.1 eggs per nest $(n=50)$ on Chainshot Island and 2.1 eggs per nest $(n=43)$ on Harbor Island in clutches that consisted of 1 to 3 eggs. On Chainshot Island every egg $(n=107)$ was lost to predation. On Harbor Island, 72 of 92 eggs were preyed upon. A trapping program, initiated on both islands, yielded 32 Marsh Rice Rats (Oryzomys palustris). Stomach contents of 23 rats were inspected, with $92.3 \%$ from Chainshot Island and $70 \%$ of the stomachs from Harbor Island containing yolk and feathers of Forster's Terns.

Key Words: Forster's Tern, Sterna forsteri, Marsh Rice Rat, Oryzomys palustris, eggs, nesting success, predation, North Carolina

Reproductive success of Forster's Terns in eastern North America has been poorly documented. In the prairie region of North America (Bergman et al. 1970; McNicholl 1982) and in Texas (Chaney et al. 1978*), most Forster's Tern eggs were lost to wave action and storm damage. In North Carolina, Parnell and Soots $\left(1979^{*}\right)$ attributed loss of some eggs to flooding, but they also described an unknown cause of mortality that left large numbers of dead chicks and broken eggs scattered throughout the colony. In subsequent years, continuing loss of eggs and colony abandonment in North Carolina was thought to be due to the effects of flooding (J. Parnell, University of North Carolina at Wilmington, Department of Biological Sciences, Wilmington, North Carolina, personal communication). Although the threat posed by mammalian predators was considered low due to the small size and isolated nature of the islands on which the birds nest, Forster's Terns nesting in the Cape Hatteras National Seashore in 1987 exhibited low reproductive success due to the apparent heavy predation by Marsh Rice Rats (Oryzomys palustris) (Cooper 1988*).

Reports of predation on eggs and chicks of Forster's Terns on the east coast of the United States are scarce; however, Marsh Rice Rats have been implicated in the nest destruction of Marsh Wrens (Cistothorus palustris) (Kale 1965) and Seaside Sparrows (Ammodramus maritimus) (Post 1981). Marsh Rice Rats, the most abundant mammalian denizen of salt-marsh habitats in coastal North Carolina (Webster et al. 1985), prey primarily on animal matter such as small crustaceans (Sharp 1967). We report heavy egg predation by Marsh Rice Rats in two Forster's Tern colonies in the Cedar Island area of coastal North Carolina.

\section{Study Area and Methods}

Field work was conducted from 15 May to 30 July 1992 on Chainshot (34 $\left.59^{\prime} \mathrm{N}, 7^{\circ} 14^{\prime} \mathrm{W}\right)$ and Harbor $\left(34^{\circ} 59^{\prime} \mathrm{N}, 76^{\circ} 13^{\prime} \mathrm{W}\right)$ islands, which are located at the junction of Core and Pamlico sounds in North Carolina. Chainshot Island is a small $(<1$ ha) natural estuarine island dominated by a Smooth Cordgrass (Spartina alterniflora) marsh and is located $2.8 \mathrm{~km}$ east from mainland Cedar Island. The wrack used as nesting habitat by Forster's Terns was composed exclusively of dead Spartina alterniflora that covered the central portion of the island. Harbor Island is a small (1 ha) natural estuarine island consisting of an upland shrub 